\title{
Perspectives in football medicine
}

Markus Waldén, Martin Hägglund, Håkan Bengtsson and Jan Ekstrand

The self-archived postprint version of this journal article is available at Linköping University Institutional Repository (DiVA):

http://urn.kb.se/resolve?urn=urn:nbn:se:liu:diva-149373

N.B.: When citing this work, cite the original publication.

The original publication is available at www.springerlink.com:

Waldén, M., Hägglund, M., Bengtsson, H., Ekstrand, J., (2018), Perspectives in football medicine, Der Unfallchirurg (Berlin. Print), 121(6), 470-474.

https://doi.org/10.1007/s00113-018-0496-5

This is a post-peer-review, pre-copyedit version of an article published in Der Unfallchirurg (Berlin. Print). The final authenticated version is available online at: https://doi.org/10.1007/s00113-018-0496-5.

Copyright: Springer Verlag (Germany)

http://www.springerlink.com/?MUD=MP 
PERSPECTIVES IN FOOTBALL MEDICINE

\section{Markus Waldén, ${ }^{1,2,3}$ Martin Hägglund, ${ }^{1,4}$ Håkan Bengtsson,, ${ }^{1,4}$ Jan Ekstrand ${ }^{1,2}$}

${ }^{1}$ Football Research Group, Linköping University, Linköping, Sweden

${ }^{2}$ Division of Community Medicine, Department of Medical and Health Sciences, Linköping University, Linköping, Sweden

${ }^{3}$ Department of Orthopaedics, Hässleholm-Kristianstad-Ystad Hospitals, Hässleholm, Sweden

${ }^{4}$ Division of Physiotherapy, Department of Medical and Health Sciences, Linköping University, Linköping, Sweden

\section{Corresponding author}

Markus Waldén, Division of Community Medicine, Department of Medical and Health Sciences, Linköping University, 58183 Linköping, Sweden

E-mail: markus.walden@telia.com

Telephone: +46733920720

Word count: 1276

Keywords: football, research, UEFA, injury, epidemiology, prevention

Schlagworte: Fußball, Forschung, UEFA, Verletzungen, Epidemiologie, Prävention 


\begin{abstract}
The high injury rate among men's professional football players is well-known. Therefore, the Union of European Football Associations (UEFA) launched an injury study already in 2001. This study, the UEFA Elite Club Injury Study (ECIS), currently includes data from a total of 51 clubs from 18 European countries with more than 14,000 registered injuries. With the $21^{\text {st }}$ World Cup (WC) in Russia just around the corner, we have from our study identified a higher match injury rate and a higher proportion of severe injuries in the European Championships compared to the preceding club competitive seasons. Moreover, we have also recently showed that the muscle injury rate is higher when players are given a recovery window of five days or less between two matches. Considering the congested match schedule of the upcoming WC, it is therefore likely that injuries and fatigue once again will be a topic of discussion this summer.
\end{abstract}

Die hohe Rate an Verletzungen im männlichen professionellen Fußball ist bekannt. Daher startete der Europäische Fußballverband (UEFA) bereits im Jahr 2001 eine Verletzungsstudie. Diese Studie, die “UEFA Elite Club Injury Study (ECIS)", schließt Daten von insgesamt 51 Clubs aus 18 Europäischen Fußballnationen mit mehr als 14.000 registrierten Verletzungen ein. Bis zur nun anstehenden 21. Fußballweltmeisterschaft in Russland, wurde in unserer Studie eine höhere Verletzungsrate in Spielen und eine höhere Rate an schweren Verletzungen in den Europäischen Turnieren identifiziert, verglichen mit den vorangegangenen Saisons in Club-Wettbewerben. Zudem konnte kürzlich gezeigt werden, dass die Rate an Muskelverletzungen ansteigt, wenn Spieler einen Genesungszeitraum von 5 Tagen oder weniger zwischen den Spielen haben. Berücksichtigt man den überfüllten Spielplan der bevorstehenden Weltmeisterschaft, ist es wahrscheinlich, dass Verletzungen und Übermüdung der Spieler erneut ein ein wichtiges Thema in diesem Sommer sein werden. 


\section{Background}

The injury risk among men's professional football players is approximately 1000 times higher compared with, for example, traditional industrial occupations otherwise associated with high risk [3]. Fortunately, the main international governing bodies for football, the Federation of International Football Associations (FIFA) and the Union of European Football Associations (UEFA), have therefore prioritised research during the 2000s to find out more about the physical and mental demands being placed on the modern footballer and the translation of these demands into injuries and illnesses [8]. The purpose of this report is to summarise the UEFA-directed research being carried out during the 2000s and to give the reader some thoughts before the upcoming $21^{\text {st }}$ FIFA World Cup (WC) in Russia this summer.

\section{The UEFA injury surveillance}

At the request of their former president, Lennart Johansson, UEFA initiated its injury surveillance project already in 1999. The first step in this project was a discussion within the Medical Committee about the optimal methodological design and system for injury reporting in men's professional football [4]. This work ended up in a UEFA methodological consensus for injury definitions and data collection procedures (Table 1) [14], and two pilot studies on the men's premier leagues in Sweden and Denmark in January 2001 [13, 23]. Based on the experiences from the pilot studies, the UEFA Champions League Injury Study was launched in July 2001 [24].

Insert Table 1 near here

\section{Football Research Group}

The Scandinavian pilot studies and the UEFA Champions League Injury Study, subsequently re-named the UEFA Elite Club Injury Study (ECIS), were carried out by a research group 
based in Linköping, Sweden, under the leadership of the former vice chairman of the UEFA Medical Committee, Professor Jan Ekstrand, and two doctoral students, Markus Waldén and Martin Hägglund. Subsequently, as the study grew and the number of research projects increased, additional doctoral students, such as Karolina Kristenson and Håkan Bengtsson were added to the group. Moreover, a few established researchers and a statistician joined the group which now took the name the Football Research Group (FRG). Still, the group was mainly based in Sweden, but with the increasing global interest for the study and the possibility of carrying out studies beyond the traditional injury and illness surveillance objectives [21, 29], FRG became truly international a few years ago by also recruiting people outside Scandinavia with different skills and merits to better understand the complex nature of professional football (Table 2).

Insert Table 2 near here

\section{The UEFA Elite Club Injury Study}

The UEFA-ECIS currently (as per February, 2018) includes data from a total of 51 clubs from 18 European countries with more than 14,000 injuries registered in our database. Briefly, a typical 25-player professional squad will face approximately 50 time-loss injuries each season [6]. Most of these injuries are located to the lower limbs with the single most frequent injury sub-type being injury to the hamstring muscle group. Interestingly, few and less severe injuries are intimately coupled to team success [17]. For example, a lower injury burden (days lost per 1000 exposure hours) and higher match availability were both significantly associated with a higher final league ranking and an increase in the UEFA Season Club Coefficient.

\section{The importance of sub-studies}


In addition to getting the overall big picture of the injury characteristics as outlined above, it is also important to study the occurrence of, and potential risk factors for, different injury subtypes. It could be argued, from a prevention perspective, that such research should mainly target injuries with a high injury burden such as the hamstring injury (a frequent injury with a short to moderate lay-off) or the anterior cruciate ligament (ACL) injury (an infrequent injury, but with a long lay-off) [1, 17]. However, it could also be argued that it is of similar importance to focus on injuries such as concussion even if the injury burden is low (an infrequent injury with usually a short lay-off), but where the short-term and long-term consequences can be devastating. In line with these arguments, we have designed and carried out sub-studies on hamstring injuries, ACL injuries and concussions, but also on, for example, groin injuries and medial collateral ligament (MCL) injuries of the knee (Table 3).

\section{Insert Table 3 near here}

\section{Time-trends in injury rate}

Using basically the same methodological approach consistently over the years, we have been able to carry out trend analyses for injuries in general and for a few specific injury sub-types on a large and robust dataset (Table 4). All in all, it seems that the overall injury rate has been essentially unchanged since 2001, but that the injury panorama has changed to some extent [9]. Muscle injuries continue to be the predominant problem among the players and the most frequent injury sub-type, the hamstring injury, has in fact increased by on average $2.3 \%$ per year [11]. On the other hand, ligament injuries in general appear to have a decreasing trend [9], including injuries such as to the medial collateral ligament of the knee and the lateral ligaments of the ankle $[20,26]$.

\section{Insert Table 4 near here}




\section{Perspectives in national football}

The bottomline of all epidemiological sports injury research is to collect detailed data on the extent of an injury problem to be able to identify possible risk factors and to evaluate the efficacy of any preventive measures that have been introduced. While the UEFA-ECIS investigates this sequence at the highest possible playing level, the results cannot be used to draw conclusions about injuries in other settings such as men's amateur and recreational football or women's and youth football. Whereas the overall injury risk in general decreases with the playing level [3], there are emerging evidence that re-injuries are a relatively bigger problem at lower levels where the medical support is sub-optimal or non-existent [18].

Consequently, large-scale injury surveillance and prevention studies on players regardless of age, sex and playing level are encouraged from all continents of the football family.

\section{Perspectives in international football}

With the $21^{\text {st }}$ FIFA WC around the corner, we hope that the fantastic players from all around the world will be injury-free and fit to perform at their best. Unfortunately, this has not always been the case; remember the $17^{\text {th }}$ WC in 2002 that was ironically termed "the World Cup in Fatigue" by the media. From the inaugural season of the UEFA-ECIS in 2001-2002, a total of 65 players also participated in the WC 2002 [5]. However, 29\% of them incurred injuries during the tournament and $32 \%$ performed below their normal standard as evaluated by an expert panel. Moreover, $60 \%$ of the players who had played more than one match per week before the WC either incurred injuries or underperformed during the tournament.

So, what are the indications that the situation will be different this summer? Our own studies on the UEFA Men's European Championships have consistently identified a higher match injury rate and a higher proportion of severe injuries (around one-quarter of all injuries) in the 
tournaments compared to the preceding club competitive seasons [15, 25]. Moreover, very recent findings show that the muscle injury rate during club-season matches is approximately $20 \%$ higher when players are given a recovery window of five days or less between two matches compared to longer recovery [2]. This increased rate of muscle injury following short recovery windows could possibly be the result of players being forced to play another match while still fatigued and insufficiently recovered from a previous match exposure. Considering the congested match schedule of the upcoming WC, with the majority of matches being played within a five-day recovery window, it is likely that player fatigue will be a topic of discussion around this WC as well. 


\section{Acknowledgements}

The authors would like to thank the participating clubs for their participation in the study.

The Football Research Group has been established in Linköping, Sweden, in collaboration with Linköping University and through grants from the Union of European Football Associations, the Swedish Football Association, the Football Association Premier League Limited, and the Swedish National Centre for Research in Sports.

\section{Competing interests}

There is no conflict of interest.

\section{Twitter}

@MarkusWalden, @MHgglund, @hockanB, @janekstrand, @frgsweden 


\section{REFERENCES}

1. Bahr R, Clarsen B, Ekstrand J (2017) Why we should focus on the burden of injuries and illnesses, not just their incidence. Br J Sports Med Published Online First [11 Oct 2017]. doi:10.1136/bjsports-2017-098160

2. Bengtsson H, Ekstrand J, Waldén M, Hägglund M (2017) Muscle injury rate in professional football is higher in matches played within 5 days since the previous match: a 14-year prospective study with more than 130000 match observations. Br J Sports Med Published Online First: [3 Nov 2017]. doi:10.1136/ bjsports-2016-097399

3. Drawer S, Fuller CW (2002) Evaluating the level of injury in English professional football using a risk based assessment process. Br J Sports Med 36:446-451

4. Ekstrand J, Karlsson J (2003) The risk for injury in football. There is a need for a consensus about definition of injury and the design of studies. Scand J Med Sci Sports $13: 147-149$

5. Ekstrand J, Waldén M, Hägglund M (2004) A congested football calendar and the wellbeing of players: correlation between match exposure of European footballers before the World Cup 2002 and their injuries and performances during that World Cup. Br J Sports Med 38:493-497

6. Ekstrand J, Hägglund M, Waldén M (2011) Injury incidence and injury pattern in professional football - the UEFA injury study. Br J Sports Med 45:553-558

7. Ekstrand J, Healy J, Waldén M, Lee J, English B, Hägglund M (2012) Hamstring muscle injuries in professional football: the correlation of MRI findings with return to play. Br J Sports Med 46:112-117

8. Ekstrand J, Dvorak J, D'Hooghe M (2013) Sport medicine research needs funding: the International football federations are leading the way. Br J Sports Med 47:726-728 
9. Ekstrand J, Hägglund M, Kristenson K, Magnusson H, Waldén M (2013) Fewer ligament injuries but no preventive effect on muscle injuries and severe injuries: an 11year follow-up of the UEFA Champions League injury study. Br J Sports Med 47:732737

10. Ekstrand J, van Dijk CN (2013) Fifth metatarsal fractures among male professional footballers: a potential career-ending disease. Br J Sports Med 47:754-758

11. Ekstrand J, Waldén M, Hägglund M (2016) Hamstring injuries have increased by $4 \%$ annually in men's professional football, since 2001: a 13-year longitudinal analysis of the UEFA Elite Club Injury Study. Br J Sports Med 50:731-737

12. Gajhede-Knudsen M, Ekstrand J, Magnusson H, Mafulli N (2013) Recurrence of Achilles tendon injuries in elite male football players is more common after early return to play: an 11-year follow-up of the UEFA Champions League injury study. Br J Sports Med 47:763-768

13. Hägglund M, Waldén M, Ekstrand J (2005) Injury incidence and distribution in elite football - a prospective study of the Danish and the Swedish top divisions. Scand J Med Sci Sports 15:21-28

14. Hägglund M, Waldén M, Bahr R, Ekstrand J (2005) Methods for epidemiological study of injuries to professional football (soccer) players: developing the UEFA model. Br J Sports Med 39:340-346

15. Hägglund M, Waldén M, Ekstrand J (2009) UEFA injury study - an injury audit of European Championships 2006 to 2008. Br J Sports Med 43:483-489

16. Hägglund M, Zwerver J, Ekstrand J (2011) Epidemiology of patellar tendinopathy in elite male soccer players. Am J Sports Med 39:1906-1911 
17. Hägglund M, Waldén M, Magnusson H, Kristenson K, Bengtsson H, Ekstrand J (2013) Injuries affect team performance negatively in professional football: An 11-year followup of the UEFA Champions League injury study. Br J Sports Med 47:738-742

18. Hägglund M, Waldén M, Ekstrand J (2016) Injury recurrence is lower at the highest professional football level than at national and amateur levels: does sports medicicine and sports physiotherapy deliver? Br J Sports Med 50:751-758

19. Lubberts B, D’Hooghe P, Bengtsson H, DiGiovanni CW, Calder J, Ekstrand J (2017) Epidemiology and return to play following isolated syndesmotic injuries of the ankle: a prospective cohort study of 3677 male professional footballers in the UEFA Elite Club Injury Study. Br J Sports Med Published Online First [21 Dec 2017].

doi:10.1136/bjsports-2017-097710

20. Lundblad M, Waldén M, Magnusson H, Karlsson J, Ekstrand J (2013) The UEFA injury study: 11-year data concerning $346 \mathrm{MCL}$ injuries and time to return to play. Br J Sports Med 47:759-762

21. McCall A, Dupont G, Ekstrand J (2016) Injury prevention strategies, coach compliance and player adherence of 33 of the UEFA Elite Club Injury Study teams: a survey of teams' head medical officers. Br J Sports Med 50:725-730

22. Nilsson M, Hägglund M, Ekstrand J, Waldén M (2013) Head and neck injuries in professional soccer. Clin J Sports Med 23:255-260

23. Waldén M, Hägglund M, Ekstrand J (2005) Injuries in Swedish elite football - a prospective study on injury definitions, risk for injury and injury pattern during 2001. Scand J Med Sci Sports 15:118-125

24. Waldén M, Hägglund M, Ekstrand J (2005) UEFA Champions League study: a prospective study of injuries in professional football during the 2001-2002 season. Br J Sports Med 39:542-546 
25. Waldén M, Hägglund M, Ekstrand J (2007) Football injuries during European Championships 2004-2005. Knee Surg Sports Traumatol Arthrosc 15:1155-1162

26. Waldén M, Hägglund M, Ekstrand J (2013) Time-trends and circumstances surrounding ankle injuries in men's professional football: an 11-year follow-up of the UEFA Champions League injury study. Br J Sports Med 47:748-753.

27. Waldén M, Hägglund M, Magnusson H, Ekstrand J (2016) ACL injuries in men’s professional football: a 15-year prospective cohort study on time trends and return-toplay rates reveals only $65 \%$ of players still play at the top level 3 years after ACL rupture 50:744-750

28. Werner J, Hägglund M, Waldén M, Ekstrand J (2009) UEFA injury study: a prospective study of hip and groin injuries in professional football over seven consecutive seasons. Br J Sports Med 43:1036-1040

29. Windt J, Ekstrand J, Khan KM, McCall A, Zumbo BD (2017) Does player unavailability affect football teams' match physical outputs? A two-season study of the UEFA Champions League. J Sci Med Sport Published Online First [24 Aug 2017]. doi:10.1016/j.jsams.2017.08.007 


\section{TABLE AND FIGURE LEGENDS}

Table 1 UEFA methodological consensus on injury definitions and data collection procedures

Table 2 Football Research Group as per February, 2018

Table 3 Summary of main sub-studies carried out on specific injury types

Table 4 Summary of studies investigating time-trends in injury rates 
Table 1 UEFA methodological consensus on injury definitions and data collection procedures

Item

Study design

Exposure factor

Study period

Data collection forms

Study manual

Contact person

Inclusion criterion

Definition of injury

Injury severity

\section{Recommendation}

Prospective cohort study

Individual participation time recorded in minutes

At least one full football season

Baseline form with anthropometrics

Individual-based attendance record

One-page injury card with tick boxes

Including all definitions and examples on how to complete forms

A member from the medical/technical staff registers exposure and injuries

All players with a first team contract

Time-loss from participation, only injuries occurring during team activities

Based on lay-off from the date of injury to date of full return 
Table 2 Football Research Group as per February, 2018

\begin{tabular}{|c|c|c|}
\hline Researcher & Titles & Current working location \\
\hline Jan Ekstrand & $\mathrm{MD}, \mathrm{PhD}$ & Linköping, Sweden \\
\hline Markus Waldén & $\mathrm{MD}, \mathrm{PhD}$ & Hässleholm, Sweden \\
\hline Martin Hägglund & $\mathrm{PT}, \mathrm{PhD}$ & Linköping, Sweden \\
\hline Jón Karlsson & $\mathrm{MD}, \mathrm{PhD}$ & Gothenburg, Sweden \\
\hline Anna Nordström & $\mathrm{MD}, \mathrm{PhD}$ & Umeå, Sweden \\
\hline Magnus Forssblad & $\mathrm{MD}, \mathrm{PhD}$ & Stockholm, Sweden \\
\hline Håkan Bengtsson* & PT, PhD & Falkenberg, Sweden \\
\hline Alan McCall & $\mathrm{PhD}$ & London, UK \\
\hline Grégory Dupont & $\mathrm{PhD}$ & Clairfontaine, France \\
\hline Clare Ardern & PT, PhD & Linköping, Sweden \\
\hline Michel D'Hooghe & MD & Buges, Belgium \\
\hline Michael Davison & MBA & London, UK \\
\hline Armin Spreco** & $\mathrm{PhD}$ & Linköping, Sweden \\
\hline Matilda Lundblad & MD, PhD student & Gothenburg, Sweden \\
\hline Johann Windt & PhD student & Vancouver, Canada \\
\hline Jonas Werner & $\mathrm{MD}$ & Norrköping, Sweden \\
\hline Anna Hallén* & PTI & Linköping, Sweden \\
\hline Mariann Gajhede & PT & Aalborg, Denmark \\
\hline Henrik Hedenvik** & $\mathrm{MSc}$ & Linköping, Sweden \\
\hline * Study controllers & & \\
\hline
\end{tabular}


Table 3 Summary of main sub-studies carried out on specific injury types

Sub-study

Ekstrand et al., 2012 [7]

Ekstrand \& van Dijk, 2013 [10]

Gajhede-Knudsen et al., 2013 [12]

Hägglund et al., 2011 [16]

Lundblad et al., 2013 [20]

Nilsson et al., 2013 [22]

Waldén et al., 2013 [26]

Waldén et al., 2016 [27]

Werner et al., 2009 [28]
Injury

Hamstring injury

$5^{\text {th }}$ metatarsal fracture

Achilles tendon injury

Patellar tendon injury

MCL injury

Head injury

Ankle injury

ACL injury

Groin injury
Principal finding

$83 \%$ of the injuries were located to the biceps femoris muscle

$54 \%$ of the injuries were categorised as stress fractures

$96 \%$ of the injuries were categorised as tendinopathies

Many playing hours was a risk factor for patellar tendinopathy

$69 \%$ of the injuries were related to contact with another player or object

$27 \%$ of concussed players returned to play within 5 days

Foul play was involved in $40 \%$ of the match-related ankle sprains

$100 \%$ of ACL-reconstructed players returned to training

$64 \%$ of the injuries were categorised as adductor-related injuries

ACL denotes anterior cruciate ligament; MCL denotes medial collateral ligament 
Table 4 Summary of studies investigating time-trends in injury rates

\section{Sub-study}

Ekstrand et al., 2013 [9]

Ekstrand et al., 2016 [11]

Hägglund et al., 2016 [18] Re-injury

Lubberts et al., 2017 [19] Syndesmosis injury

Lundblad et al., 2013 [20] MCL injury

Waldén et al., 2013 [26]

Waldén et al., 2016 [27]
Injury

General

Hamstring injury

Ankle injury

ACL injury
Principal finding

A non-significant decreasing trend of on average $1.5 \%$ per year for match injuries

An increasing trend of on average $2.3 \%$ per year for hamstring injuries

A decreasing trend of on average $2.9 \%$ per year for re-injuries

An increasing trend of on average $0.3 \%$ per year for syndesmosis injuries

A decreasing trend of on average $6.9 \%$ per year for MCL injuries

A decreasing trend of on average $3.1 \%$ per year for ankle sprains

A non-significant increasing trend of on average $6.0 \%$ per year for ACL injuries

ACL denotes anterior cruciate ligament; MCL denotes medial collateral ligament 